\title{
KEWENANGAN DPRD PROVINSI JAWA TENGAH DALAM MENERIMA LAPORAN HASIL AUDIT BPK BERDASARKAN UNDANG-UNDANG NOMOR 23 TAHUN 2014 TENTANG PEMERINTAHAN DAERAH
}

\author{
Oleh : \\ Heni Tri Susilowati, A. Heru Nuswanto, Sukimin \\ Fakultas Hukum Universitas Semarang \\ heni_trisusilowati@yahoo.com, heru_nuswanto@gmail.com, sukimin@yahoo.com
}

\begin{abstract}
ABSTRAK
Penelitian ini di latarbelakangi dengan adanya Undang-Undang Nomor 23 Tahun 2014 Pedoman dan Tata Cara Dewan Perwakilan Rakyat Daerah (DPRD) menerima laporan hasil pemeriksaan audit keuangan pemerintah provinsi oleh Badan Pemeriksa Keuangan (BPK), mewajibkan bagi pemerintah daerah agar melakukan kegiatannya berdasarkan tugas dan tanggung jawab dari pejabat yang berwenang. Dalam penelitian ini akan melihat tentang kewenangan DPRD Provinsi jawa Tengah dalam menerima laporan hasil audit BPK, kendala DPRD dalam menerima laporan hasil audit BPK dan upaya mengatasinya. Jenis penelitian yang digunakan adalah yuridis sosiologis dengan spesifikasinya deskriptif analitis. Metode penentuan sampelnya adalah purposive sampling. Data yang dipergunakan adalah data primer yang diperoleh melalui wawancara didukung dengan data sekunder, kemudian di analisis secara kualitatif. Hasil penelitian menunjukan bahwa kewenangan DPRD Provinsi Jawa Tengah dalam menerima laporan hasil audit BPK sudah maksimal. Tetapi belum terlaksana dengan baik yaitu terdapat kendala dalam internal adalah tenggang waktu pembahasan yang sedikit, minimnya rancangan undang-undang, kurangnya sumber daya manusia, kurangnya proses pencatatan mengenai aset daerah, upaya dari jawaban kendala internal, berpedoman pada perundangundangan, melakukan pembahasan bersama Gubernur, menambah aspek regulasi, SDM, dan teknologi informasi, memberi sanksi/menindak lanjuti panitia kerja yang lalai mencatat pengeluaran aset daerah.
\end{abstract}

Kata kunci : kewenangan DPRD; laporan; audit keuangan;

\section{ABSTRACT}

This research is in background with the existence of Law Number 23 Year 2014 The Guidelines and Procedures of the Regional People's Legislative Assembly (DPRD) receive reports on the audit results of the provincial government's financial audit by the Supreme Audit Board (BPK), requiring local governments to perform their activities based on their duties and responsibility of the competent authority. In this research will see about the authority of Central Java Provincial DPRD in receiving BPK audit report result, obstacle of DPRD in receiving report of BPK audit result and effort to overcome it. The type of research used is sociological juridical with descriptive analytical specification. The method of determining the sample is purposive sampling. The data used are primary data obtained through interviews supported by secondary data, then analyzed qualitatively. The results showed that the authority of Central Java Provincial DPRD in receiving BPK audit report has been maximal. However, it has not been well implemented that there are internal constraints is the lack of discussion time, the lack of draft law, the lack of human resources, the lack of process of recording of local assets, the effort of the internal constraint answer, guided by the legislation, The governor, adding aspects of regulation, human resources, and information technology, sanctioned / followed up the work committee that neglected to record the expenditure of regional assets.

Keywords: DPRD authority; report; audit finance; 


\section{A. Pendahuluan}

Sehubungan dengan penentuan hasil akhir dari proses penilaian kebenaran, kepatuhan, kecermatan, kredibilitas, dan keandalan data/informasi mengenai pengelolaan dan tanggung jawab keuangan negara, berdasarkan kemampuan dalam pemeriksaan, yang akan dituangkan dalam laporan hasil pemeriksaan sebagai keputusan Badan Pemeriksa Keuangan (BPK). Sebagaimana termuat dalam UUD NRI Tahun 1945, termuat di Pembukaan Alinea IV, Pasal 20 ayat (1) dan 23E ayat (2). ${ }^{1}$ Selanjutnya dijelaskan juga bahwa Pemerintah Daerah mempunyai peran yang sangat berpengaruh disetiap daerah masing-masing, dalam mengawasi dan menerima laporan hasil keuangan setiap anggaran daerah berdasarkan otonomi daearah. Mengenai pemerintahan di jelaskan bahwa UndangUndang Nomor 23 Tahun 2014 tentang pemerintahan daerah, Pasal 9 ayat (3). ${ }^{2}$ Setiap daerah berhak dalam menetapkan kebijakan daerah untuk melaksanakan tugasnya. Dalam pembuatan laporan hasil audit yang dibuat oleh BPK yang nantinya akan diserahkan oleh Dewan Perwakilan Rakyat Daerah (DPRD). Laporan tersebut berupa laporan realisasi APBN/APBD, neraca, laporan operasional, catatan atas laporan keuangan. Laporan hasil audit BPK yang diberikan kepada DPRD yang nantinya dalam penyampaian laporan keuangan pemerintah daerah dalam dokumen terpisah.

\section{B. Perumusan Masalah}

1. Bagaimanakah kewenangan DPRD Provinsi Jawa Tengah dalam menerima laporan hasil audit BPK berdasarkan Undang-Undang Nomor 23 Tahun 2014?

2. Kendala-kendala apakah yang dihadapi oleh DPRD Provinsi Jawa Tengah dalam menerima laporan hasil audit berdasarkan Undang-Undang Nomor 23 Tahun 2014?

3. Upaya-upaya apakah yang dilakukan oleh DPRD Provinsi Jawa Tengah dalam mengatasi kendala menerima laporam hasil audit BPK berdasarkan Undang-Undang Nomor 23 Tahun 2014?

\section{Tujuan dan Manfaat Penelitian}

\section{Tujuan}

1) Untuk mengetahui kewenangan DPRD Provinsi Jawa Tengah dalam menerima laporan hasil audit berdasarkan Undang-Undang Nomor 23 Tahun 2014.

\footnotetext{
${ }^{1}$ Pasal 20 ayat (1) UUD 1945 menyebutkan bahwa: Dewan Perwakilan Rakyat memiliki fungsi legislasi, fungsi anggaran, dan fungsi pengawasan. Sedangkan Pasal 23E ayat (2) UUD 1945 menyebutkan bahwa: (2). Hasil pemeriksaan keuangan negara diserahkan kepada Dewan Perwakilan Rakyat, Dewan Perwakilan Daerah, dan Dewan Perwakilan Rakyat Daerah, sesuai dengan kewenangannya.

${ }^{2}$ Pasal 9 ayat (3) Undang-Undang Nomor 23 Tahun 2014 tentang Pemerintahan Daerah, menyebutkan bahwa: urusan pemerintahan konkuren sebagaimana dimaksud pada ayat (1) adalah urusan pemerintahan yang dibagi anatar Pemerintah Pusat, Daerah Provinsi, dan Daerah Kabupaten/Kota
} 
2) Untuk mengetahui kendala-kendala yang dihadapi oleh DPRD Provinsi Jawa Tengah dalam menerima laporan hasil audit berdasarkan Undang-Undang Nomor 23 Tahun 2014.

3) Untuk mengetahui upaya-upaya yang dihadapi oleh DPRD Provinsi Jawa Tengah dalam menerima laporan hasil audit berdasarkan Undang-Undang Nomor 23 Tahun 2014.

\section{Manfaat}

1) Manfaat teoritis

Manfaat teoritis yang diharapkan adalah dapat memberikan sumbangan pemikiran bagi bagi pengembangan Hukum Tata Negara di Indonesia, yang mengatur tentang penelitian laporan hasil audit Badan Pemeriksa Keuangan.

2) Manfaat praktis

a. Bagi pemerintah

Pemerintah selaku pembuat kebijakan, agar dalam merumuskan kebijakan tentang kewenangan DPRD Provinsi Jawa Tengah dalam menerima laporan hasil audit BPK sesuai Undang-Undang Nomor 23 Tahun 2014 tentang Pemerintahan Daerah yang akan datang dapat dijalankan dengan efektif.

b. Bagi masyarakat

Masyarakat selaku sasaran dari kebijakan pemerintah, diharapkan dapat menjadi wacana yang berharga bagi masyarakat terkait dengan menerima laporan hasil audit BPK sesuai Undang-Undang Nomor 23 Tahun 2014 tentang Pemerintahan Daerah.

\section{Tinjauan Pustaka}

\section{Tinjauan tentang Kewenangan DPRD Provinsi}

Dewan Perwakilan Rakyat Daerah Provinsi (DPRD Provinsi) adalah lembaga perwakilan rakyat daerah yang berkedudukan sebagai unsur penyelenggaraan pemerintahan daerah provinsi. DPRD Provinsi terdiri atas anggota partai politik peserta pemilihan umum yang dipilih melalui pemilihan umum. DPRD Provinsi mempunyai fungsi legislasi, anggaran, dan pengawasan yang dijalankan dalam kerangka representasi rakyat di provinsi. Pernyataan tersebut dapat dilihat dalam UUD NRI 1945, terutama Pembukaan Alinea IV, Pasal 18 ayat (3). ${ }^{3}$ Berdasarkan pengertian tersebut

${ }^{3}$ Pasal 18 ayat (3) menyebutkan bahwa: pemerintahan daerah provinsi, daerah kabupaten, dan kota memiliki Dewan Perwakilan Rakyat Daerah yang anggota-anggotanya dipilih melalui pemilihan umum. 
maka dapat disimpulkan bahwa DPRD berfungsi sebagai kontrol politik, sosial, ekonomi, dan pendidikan.

\section{Tinjauan tentang Audit Keuangan BPK}

1) Pengertian tentang Audit dan Audit keuangan

\section{a. Pengertian Audit}

Audit atau pemeriksaan dalam arti luas bermakna evaluasi terhadap suatu organisasi, sistem, proses, atau produk. Audit dilaksanakan oleh pihak yang kompeten, objektif, dan tidak memihak, yang disebut auditor. Tujuannya adalah untuk melakukan verifikasi bahwa subjek dari audit telah diselesaikan atau berjalan sesuai dengan standar, regulasi, dan praktik yang telah disetujui dan diterima. ${ }^{4}$

\section{b. Pengertian Audit Keuangan}

Audit Keuangan adalah audit terhadap laporan keuangan suatu enstitas (perusahaan atau organisasi) yang akan menghasilkan pendapat (opini) pihak ketiga mengenai relevensi, akurasi, dan kelengkapan laporan laporan tersebut.

2) Badan Pemeriksa Keuangan (BPK)

\section{a. Pengertian BPK}

BPK adalah lembaga tinggi negara dalam sistem ketatanegaraan Indonesia yang memiliki wewenang memeriksa pengelolaan dan tanggung jawab keuangan negara. Pemeriksaan adalah proses indentifikasi masalah, analisis, dan evaluasi yang dilakukan secara independen, objektif, dan profesional berdasarkan standar pemeriksaan, untuk menilai kebenaran, kecermatan, kredibilitas, dan keandalan informasi mengenai pengelolaan dan tanggung jawab keuangan negara.

\section{E. Metode Penelitian}

Metode penelitian adalah suatu proses, prinsip dan tata cara untuk memecahkan masalah-masalah yang dihadapi dalam melakukan penelitian. Penelitian hukum adalah suatu kegiatan ilmiah yang didasarkan pada metode, sistematika dan pemikiran tertentu yang bertujuan untuk mempelajari suatu atau gejala hukum tertentu dengan jalan menganalisisnya. ${ }^{5}$

\footnotetext{
${ }^{4}$ Alkitit" (online) (https://id.wikipedia.org/wiki/Audit, diakses 27 April 2017).

${ }^{5}$ Amarudin dan ZainalAsikin."Pengantar Metode Penelitian Hukum”. (Jakarta : Rajawali Press. 2013), halaman 14.
} 


\section{Jenis/Tipe Penelitian}

Jenis/tipe penelitian yang di pergunakan dalam penelitian ini adalah yuridis sosiologis, yaitu jenis penelitian yang dilakukan secara langsung dengan melihat kenyataan yang ada dalam praktek dilapangan. Jenis penelitian ini digunakan karena peneliti ingin mengkaji tentang kewenangan DPRD Provinsi Jawa Tengah dalam menerima laporan hasil audit BPK berdasarkan Undang-Undang Nomor 23 Tahun 2014 tentang Pemerintahan Daerah.

\section{Spesifikasi Penelitian}

Spesifikasi penelitian yang digunakan dalam penelitian ini adalah deskriptif analitis, yaitu penelitian yang bertujuan memberikan gambaran tentang objek yang diteliti. Spesifikasi ini dipergunakan karena peneliti ingin menggambarkan tentang kewenangan DPRD Provinsi Jawa Tengah dalam menerima laporan hasil audit BPK berdasarkan Undang-Undang Nomor 23 Tahun 2014 tentang Pemerinntahan Daerah.

\section{Metode Penentuan Sampel}

Sampel dalam penelitian ini ditentukan bedasarkan metode purposive sampling, pengertian purposive sampling yaitu teknik pengambilan sampel dengan mengambil kelompok subjek tertentu dari populasi yang akan diteliti. Hal ini dilakukan karena adanya keterbatasan waktu, tenaga, biaya yang ada pada peneliti. Populasi dalam penelitian ini adalah kewenangan DPRD Provinsi Jawa Tengah, sedangkan sampelnya adalah kewenangan menerima laporan hasil audit BPK.

\section{Metode Pengumpulan Data}

1) Data primer

Yaitu data yang diperoleh dengan penelitian langsung dari obyeknya. Penelitian secara langsung ini dilakukan dengan cara wawancara kepada Bapak Bambang Joyo Supeno, S.H., M.Hum a.n Komisi A DPRD Provinsi Jawa Tengah, wawancara menggunakan daftar pertanyaan yang telah disusun dahulu (kuesioner) agar proses tanya jawab berjalan lancar.

2) Data sekunder

Data sekunder adalah data yang diperoleh melalui studi kepustakaan untuk mendapat konsepsi-konsepsi, teori-teori, pendapat-pendapat atau landasan teoritis yang berhubungan erat dengan permasalahan.

\section{Analisa Data}

Metode analisa data yang digunakan dalam penelitian ini adalah metode analisa kualitatif yaitu analisa yang bersifat non statistik atau non matematis. Data yang ada 
baik berupa hasil wawancara maupun data kepustakaan akan dianalisis isinya dengan menggunakan asas-asas hukum, teori-teori hukum, pendapat para ahli, dan peraturan perudang-undangan yang ada.

\section{F. Hasil dan Pembahasan}

1. Kewenangan DPRD Provinsi Jawa Tengah Dalam Menerima Laporan Hasil Audit BPK Berdasarkan Undang-Undang Nomor 23 Tahun 2014 tentang Pemerintahan Daerah

DPRD mempunyai tiga fungsi, yaitu pembentukan peraturan daerah, anggaran dan pengawasan. Dalam tugas dan kewenangan DPRD, yaitu salah satunya melaksanakan pengawasan terhadap pelaksanaan peraturan daerah dan APBD, serta pelaksanaan tindak lanjut hasil pelaksanaan laporan keuangan oleh BPK. DPRD menerima laporan hasil pemeriksaan audit keuangan pemerintah provinsi oleh BPK dalam suatu rapat paripurna tentang penyerahan laporan hasil pemeriksaan keuangan pemerintah provinsi oleh BPK, dengan Prosedur: pembukaan rapat paripurna oleh pimpinan DPRD, penyampaian/presentasi hasil pemeriksaan keuangan oleh BPK, penyerahan hasil pemeriksaan keuangan pemerintah provinsi dari BPK kepada pimpinan DPRD, pembentukan panitia kerja untuk melakukan pembahasan hasil laporan pemeriksaan keuangan dari BPK. Hasil laporan pemeriksaan keuangan pemerintah provinsi oleh BPK sekali dalam 1 tahun, namun apabila panitia kerja menemukan aspek-aspek tertentu mengenai ketidaksamaan antara BPK sebagai pemeriksa dengan DPRD sebagai pengawasan, maka DPRD dapat mengembalikan laporan keuangan ke BPK agar BPK menindak lanjuti pendalaman.

Standar hasil pemeriksaan laporan keuangan oleh BPK yang diterima oleh DPRD, yaitu: laporan hasil pemeriksaan keuangan, laporan hasil pemeriksaan kinerja, laporan hasil pemeriksaan dengan tujuan tertentu. Dari ketiga standar tersebut, BPK akan memberikan opini:

a. Opini wajar tanpa pengecualian;

b. Opini wajar dengan pengecualian;

c. Opini tidak wajar;

d. Pernyataan menolak memberikan opini.

Setelah DPRD menerima hasil laporan pemeriksaan keuangan pemerintah provinsi dari BPK, dan ditemukan atau ada catatan dari BPK, maka Pimpinan DPRD membentuk panitia kerja untuk melakukan pembahasan atas laporan hasil pemeriksaan BPK tersebut, adapun tahapan yang harus dilaksanakan, yaitu: 
a. Pembahasan yang dilakukan DPRD paling lambat 2 minggu setelah menerima laporan pemeriksaan dari BPK;

b. Pembahasan oleh DPRD diselesaikan dalam waktu 1 minggu;

c. Dapat melakukan konsultasi ke BPK

d. Pimpinan DPRD mengagendakan dalam pembahasan rapat paripurna.

DPRD melakukan pengawasan terhadap pemerintah provinsi atas pelaksanaan tindak lanjut hasil pemeriksaan BPK, dengan melakukan koordinasi dengan tim tindak lanjut laporan hasil pemeriksaan BPK yang dibentuk oleh Gubernur, dan melakukan monitoring.

2. Kendala-kendala yang dihadapi oleh DPRD Provinsi Jawa Tengah dalam menerima laporan hasil audit berdasarkan Undang-Undang Nomor 23 Tahun 2014;

1) Pasal 40 ayat (1) Minimnya rancangan undang-undang/peraturan daerah yang disahkan oleh DPRD, praktis hanyalah APBD yang disahkan itupun mau tidak mau harus disahkan setiap tahunnya dengan terbukti pada tahun 2014;

2) Pasal 327 ayat (1) dan (2) Kurangnya proses pencatatan, pembiayaan, dan pelaporan dalam aset yang tidak dicatat dalam buku inventaris/buku besar.

3) Kurangnya sumber daya manusia, pemerintah daerah belum memadai/belum selaras untuk mendukung laporan standar akuntansi pemerintahan (SAP) berbasis akrual;

4) Tenggang waktu pembahasan yang sedikit, yaitu 1 minggu oleh panitia kerja untuk membahas dan 2 minggu setelah DPRD provinsi menerima hasil pemeriksaan dari BPK, DPRD bekerja keras dan focus yang nantinya akan dibahas di rapat paripurna

3. Upaya-upaya apakah yang dilakukan oleh DPRD Provinsi Jawa Tengah dalam mengatasi kendala menerima laporam hasil audit BPK berdasarkan UndangUndang Nomor 23 Tahun 2014

1) Penambahan dalam pengesahan rancangan undang-undang/peraturan daerah, dalam APBD yang setiap tahunnya harus dilaksanakan oleh DPRD di rapat paripurna guna mencapai tujuan laporan audit yang sesuai perundang-undangan. Didalam pembahasan DPRD Provinsi dan Gubernur yang membahas hasil laporan audit dari BPK diminta dalam pembahasan tersebut biasanya hanya mengacu APBD tetapi perlu kita ketahui bahwa perlu adanya penambahan standar akuntansi pemerintah guna penambahan (RAPBD) terkait Pasal 91 ayat (2) tersebut;

2) Ketertiban dalam pembuatan buku inventaris/buku besar yang harus diisi pada saat penerimaan laporan hasil audit maupun pengeluaran keuangan yang digunakan untuk membeli barang (aset negara), yang selalu di-update mengenai keberadaan, 
kondisi, dan lokasi aset. Maka pimpinan DPRD memberikan sanksi/menindak lanjuti panitia kerja yang lalai dalam menulis pengeluaran aset daerah di buku besar, agar panitia tersebut bertanggung jawab mengganti rugi atas kinerja yang dilakukannya terkait Pasal 327 ayat (1) dan (2).

3) Pemerintah daerah harus memiliki dokumen perencanaan strategis yang komprehensif untuk menjalankan standar akuntansi pemerintah (SAP) berbasis akrual, pemerintah daerah agar menyusun roadmap dalam menjalankan laporan SAP berbasis akrual, maka pemerintah daerah agar menyajikan langkah tektis dalam aspek regulasi, SDM, dan teknologi informasi guna mencapai rencana kerja rinci yang menggambarkan apa yang harus dilakukan untuk mencaai tujuan untuk masa yang akan datang.

4) Upaya yang dilakukan tetap mematuhi waktu yang telah ditentukan oleh perundang-undangan baik Undang-Undang Republik Indonesia Nomor 23 Tahun 2014 tentang Pemerintahan Daerah, maupun Undang-Undang Republik Indonesia Nomor 15 Tahun 2006 tentang Badan Pemeriksa Keuangan, bagaimanapun juga harus mentaati peraturan yang ada. Namun kita juga dapat melihat kendala-kendala laporan diluar eksternal dan internal, jika apabila terdapat kendala dari dalam seperti internal (DPRD) yang kurang tepat waktu maka kita memberikan sanksi kepada pegawai yang lambat/mengulur waktu maka agar tetap berpedoman pada peraturan perundang-undangan;

\section{G. Penutup}

\section{Simpulan}

a. Kewenangan DPRD Provinsi Jawa Tengah dalam menerima laporan hasil audit BPK berdasarkan Undang-Undang Nomor 23 Tahun 2014 tentang Pemerintahan Daerah telah sesuai dengan ketentuan peraturan perundang-undangan yaitu dengan terbentuknya opini wajar tanpa pengecualian tersebut harus selalu dipertahankan dalam laporan hasil pemeriksaan BPK, karena pemerintah provinsi Jawa Tengah 3 tahun ini masih menempati opini wajar tanpa pengecualianyang harus tetap dipertahankan untuk tahun kedepannya.

b. Kendala-kendala yang muncul dalam kewenangan DPRD Provinsi Jawa Tengah dalam menerima laporan hasil audit BPK berdasarkan Undang-Undang Nomor 23

Tahun 2014, adalah sebagai berikut:

1) Minimnya rancangan undang-undang/peraturan daerah;

2) Kurangnya proses pencatatan, pembiayaan, dan pelaporan mengenai aset daerah. 
3) Kurangnya sumber daya manusia dalam laporan standar akuntansi pemerintah (SAP) berbasis akrual;

4) Tenggang waktu yang sedikit

c. Upaya-upaya apakah yang dilakukan oleh DPRD Provinsi Jawa Tengah dalam mengatasi kendala menerima hasil audit BPK berdasarkan Undang-Undang Nomor 23 Tahun 2014 adalah, sebagai berikut:

1) Upaya mengatasinya dengan cara melakukan pembahasan peraturan bersama Gubernur agar tercapainya suatu kinerja dalam laporan audit keuangan yang bersifat standar akuntansi pemerintah (SAP) berbasis akrual;

2) Upaya mengatasinya dengan cara memberikan saksi/menindak lanjuti panitia kerja yang lalai dalam menulis pengeluaran aset daerah di buku besar, agar panitia kerja tersebut bertanggungjawab menganti rugi atas kinerja yang dilakukannya;

3) Upaya mengatasinya dengan cara menyusun roadmap guna menjalankan laporan standar akuntansi pemerintah berbasis akrual dan menyajikan langkah tektis dalam aspek regulasi, sumber daya mausia, dan teknologi informasi agar mencapai rencana kerja rinci yang menggambarkan apa yang harus dilakukan untuk mencapai tujuan;

4) Upaya untuk mengatasinya dengan tetap berpedoman pada peraturan peerundang-undangan yang ada dan memberikan sanksi kepada pegawai yang lambat/mengulur waktu;

\section{Saran}

a. Kewenangan DPRD provinsi didalam pengawasan laporan hasil audit perlu memperhatikan atau meneliti kembali hasil laporan yang diserahkan oleh BPK, agar didalam keputusan rapat paripurna menjalankan standar akuntansi pemerintah yang sesuai prosedur yang ditetapkan yaitu berbasis akrual;

b. Perlu adanya koordinasi yang jelas antara DPRD dan BPK terkait perubahan regulasi. Adanya koordinasi ini bertujuan agar penyelesaian laporan hasil audit BPK dapat berjalan dengan baik dan tepat waktu.

\section{DAFTAR PUSTAKA}

\section{a. Buku-buku :}

Amarudin danAsikin, Zainal. Pengantar Metode Penelitian Hukum. Jakarta : Rajawali Press. 2013), halaman 14.

Huda, Ni'matul. Hukum Pemerintah Daerah..Bandung : Nusa Media. 2010. Halaman 50. 
HSSalim dan Nurbani Septiana Erlies. Penelitian Teori Hukum pada Penelitian Tesis dan Disertasi.Jakarta : PT. Raja Grafindo Persada. 2013. Halaman 20.

Sunarno, Siswanto. Hukum Pemerintah Daerah di Indonesia. Sinar Grafika: Jakarta, 2009.

Sunggno, Bambang. Metodologi Penelitian Hukum. Jakarta: Rajawali Pers, 2010.

Sutedi, Adrian. Hukum Keuangan Negara. Sinar Grafika: Jakarta, 2010.

Tjandra, W. Riawan. Hukum Keuangan Negara. PT Grasindo: Jakarta, 2014.

\section{b. Peraturan Perundang-undangan :}

Sekertaris Negara RI, Undang-Undang Dasar Negara Republik Indonesia Tahun 1945. Jakarta, 1945.

Sekertaris Negara RI, Undang-Undang Nomor 15 Tahun 2006 tentang Badan Pemeriksa Keuangan(BPK). Jakarta, 2006.

Sekertaris Negara RI, Undang-Undang Nomor 17 Tahun 2003 tentang Keuangan Negara.

Sekertaris Negara RI, Undang-Undang Nomor 23 Tahun 2014 tentang Pemerintah Daerah. Semarang, 2014.

\section{c. Website :}

Azhar Aziz, Harry, "Pengertian Badan Pemeriksa Keuangan" (online) (https://id.wikipedia.org/wiki/Badan_Pemeriksa_Keuangan_Republik_Indone sia., Diakses Kamis, 27 April 2017)

Damang, "Pengertian Kewenangan-Negara Hukum" (online) (http://www.negarahukum.com/hukum/pengertiankewenangan.html.,DiaksesKamis, 27 April 2017)

Kuntadi, cris, "Auditor dan Pengamatan Kebijakan Publik:Audit Laporan Keuangan Pemerintah" (online) (http://criskuntadi.blogspot.co.id/2008/10/audit-laporankeuangan-pemerintah.html., Diakses Kamis, 27 April 2017)

Kuntadi, Cris, "Auditor dan Pengamatan Kebijakan Publik:PERAN BPK-RI DALAM SEKTOR PUBLIK ATAS PEMERINTAH DAERAH" (online) (http://criskuntadi.blogspot.co.id/2008/11/peranan-bpk-ri-dalam-auditsektor.html., Diakses Kamis, 27 April 2017)

Lawfirm, "Pengertian Kewenangan-SUDUT HUKUM" (online) (http://www.suduthukum.com/2016/02/pengertian-kewenangan.html., Diakses Kamis, 27 April 2017)

Wikipedia, "Pengertian Audit" (online) (https://id.wikipedia.org/wiki/Audit., Diakses Kamis, 27 April 2017) 
Wikipedia, "Pengertian Pemerintah Daerah di Indonesia" (online) (https://id.wikipedia.org/wiki/Pemerintahan_daerah_di_Indonesia., Diakses Kamis, 27 April 2017)

\section{d. Wawancara :}

Supeno, Bambang Joyo. Komisi A DPRD Provinsi Jawa Tengah. Wawancara. Semarang. 17 Januari 2018. 